\title{
Data collection instrument for hematological diseases in an outpatient setting: a validation study
}

\author{
Instrumento de coleta de dados para doenças hematológicas em ambulatório: estudo de validação
}

Instrumento de recolección de datos para enfermedades hematológicas en ambulatorio: un estudio de validez

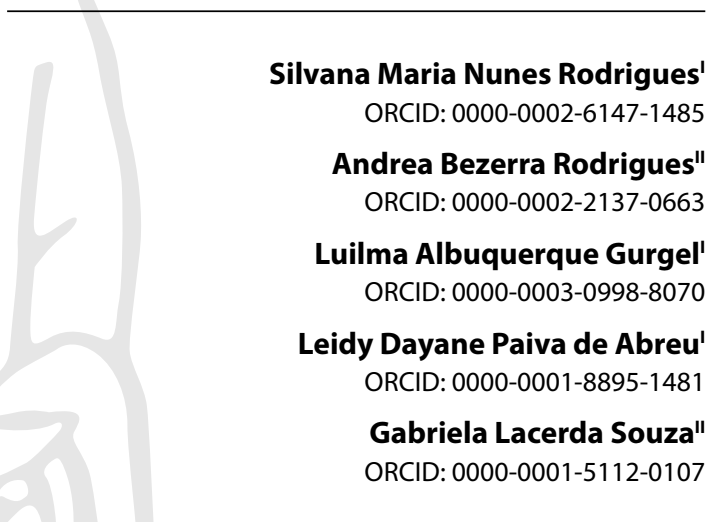

'Universidade Estadual do Ceará. Fortaleza, Ceará, Brazil. "Universidade Federal do Ceará. Fortaleza, Ceará, Brazil.

How to cite this article: Rodrigues SMN, Rodrigues AB, Gurgel LA, Abreu LDP, Souza GL. Data collection instrument for hematological diseases in an outpatient setting: a validation study. Rev Bras Enferm. 2021;74(3):e20201034. https://doi.org/10.1590/0034-7167-2020-1034

\section{Corresponding author:}

Silvana Maria Nunes Rodrigues E-mail: biasilvana2011@hotmail.com

EDITOR IN CHIEF: Antonio José de Almeida Filho ASSOCIATE EDITOR: Alexandre Balsanelli

Submission: $10-20-2020$

Approval: 01-06-2021

\section{ABSTRACT}

Objectives: to build and validate a data collection instrument for onco-hematological patients undergoing outpatient chemotherapy. Methods: methodological study that aimed to build a scientifically consistent data collection instrument to evaluate hematological patients. There were five stages: identification of empirical indicators, evaluation of empirical indicators by focus group, construction of the instrument, content validation by judges and clinical validation. Built based on the Theory of Basic Human Needs of Horta, adjusted by Garcias and Cubas. Results: the built instrument contains data on patient identification, perception and expectations related to the disease, assessment of psychobiological, psychosocial and psychospiritual needs. It reached $95 \% \mathrm{CVI}$, ensuring the instrument's content validity and Cronbach's alpha test with a reliability of 0.93 . Conclusions: the instrument is a valid technology to assist nurses in data collection and may serve as a tool for onco-hematological nursing care, teaching and research.

Descriptors: Nursing Process; Validation Studies; Chemotherapy; Neoplasms; Hematology.

\section{RESUMO}

Objetivos: construir e validar um instrumento de coleta de dados para pacientes oncohematológicos em tratamento quimioterápico ambulatorial. Métodos: estudo metodológico que objetivou construir um instrumento de coleta de dados consistente cientificamente para avaliar pacientes hematológicos. Foram cinco etapas: identificação dos indicadores empíricos, avaliação dos indicadores empíricos por grupo focal, construção do instrumento, validação de conteúdo por juízes e validação clínica. Construído com base na Teoria das Necessidades Humanas Básicas de Horta, ajustada por Garcias e Cubas. Resultados: o instrumento construído contém dados de identificação do paciente, percepção e expectativas relacionadas à doença avaliação das necessidades psicobiológicas, psicossociais e psicoespirituais. Atingiu IVC de $95 \%$, assegurando a validade de conteúdo do instrumento e teste alfa de Cronbach com confiabilidade de 0,93 . Conclusões: o instrumento constitui-se em uma tecnologia válida para auxiliar o enfermeiro na coleta de dados e poderá servir como ferramenta para a assistência, ensino e pesquisa em enfermagem onco-hematológica.

Descritores: Processo de Enfermagem; Estudos de validação; Quimioterapia; Neoplasias; Hematologia.

\section{RESUMEN}

Objetivos: construir y validar instrumento de recopilación de datos para pacientes oncohematológicos en tratamiento quimioterápico en ambulatorio. Métodos: estudio metodológico objetivó construir un instrumento de recopilación de datos consistente científicamente para evaluar pacientes hematológicos. Fueron cinco etapas: identificación de indicadores empíricos, evaluación de esos por grupo focal, construcción del instrumento, validez de contenido por jueces y validez clínica. Construido basado en Teoría de las Necesidades Humanas Básicas de Horta, ajustada por Garcias y Cubas. Resultados: el instrumento construido contiene datos de identificación del paciente, percepción y expectativas relacionadas a la enfermedad, evaluación de necesidades psicobiológicas, psicosociales y psicoespirituales. Atingió IVC de $95 \%$, asegurando la validez de contenido del instrumento y test alfa de Cronbach con confiabilidad de 0,93. Conclusiones: el instrumento se constituye en una tecnología válida para auxiliar el enfermero en la recopilación de datos y podrá servir como herramienta para la asistencia, enseñanza e investigación en enfermería oncohematológica. Descriptores: Proceso de Enfermería; Estudios de Validez; Quimioterapia; Neoplasias; Hematología. 


\section{INTRODUCTION}

Currently, antineoplastic chemotherapy (CTX) remains an indispensable therapeutic option, which has the best cure results for many types of tumors, increasing the survival of cancer patients ${ }^{(1-2)}$. It is a systemic treatment of cancer administered at regular intervals, which vary according to therapeutic regimens ${ }^{(3)}$.

Oncological patients are exposed to several sources of physical and psychological suffering and, to prevent and reduce it, several interventions can be implemented. However, the formulation of such interventions is done by assessing the human needs presented by the patient ${ }^{(4)}$. Individualized care is associated with quality of care. Thus, personalization of care is one of the means for improving nursing care for cancer patients ${ }^{(5)}$.

Regarding the quality of care, the systematization of nursing care has brought great advances in recent years, and is configured as a valid tool for obtaining positive results for patients and nursing professionals ${ }^{(6)}$. Therefore, knowing that the nursing process is made up of interrelated and dynamic stages, and that the initial stage of building the patient's history is essential for the development of the others, there is a need to use complete data collection instruments and easy to understand, which allows obtaining relevant data for the nurse ${ }^{(7)}$.

Once validated, this tool is considered to bring contributions to the outpatient care of patients with onco-hematological diseases undergoing antineoplastic treatment, given the lack of similar technology published in journals in the area.

\section{OBJECTIVES}

To build and validate a data collection instrument for oncohematological patients undergoing outpatient chemotherapy.

\section{METHODS}

\section{Ethical aspects}

The ethical precepts established by Resolution No. 466/2012 of the National Health Council followed, so that the study was approved by the Research Ethics Committee of the Federal University of Ceará.

\section{Design, study location and period}

Methodological study guided by the tool Consolidated Criteria for reporting qualitative research (COREQ), referenced on the Equator network, which presents a checklist of 32 items to provide subsidies to studies using focus groups ${ }^{(8)}$. The study was developed according to the methodological framework of the Theory of Basic Human Needs, by Wanda de Aguiar Horta ${ }^{(9)}$, from February to October 2017.

\section{Population and sample}

It was carried out in a focus group, by a specialist nurse coordinator, from a CTX outpatient clinic, who is trained in leading a focus group, and with four nurses from a chemotherapy outpatient clinic of a teaching hospital, belonging to the Hospital
Complex of Universidade Federal do Ceará (UFC). And it aimed to evaluate the grouping of the empirical indicators found and their relationship with altered BHN in the onco-hematological patient, through analysis of the interviews with content analysis of the participants'responses. The choice of participants was for convenience, and they were approached in person, considering the experience of nurses in the care of this public. There were no withdrawals from participation. The interviews were recorded and transcribed shortly after their end, in addition to field notes taken during the group. There were two meetings, considering that the data obtained in the first meeting were returned to the participants for possible corrections and validation.

After the elaboration of the instrument, it was validated in terms of content by seven judges with experience in onco-hematology and systematization of nursing care. Jasper's criteria ${ }^{(10)}$ were used to recruit the judges: possess specialized skill/knowledge, which makes the professional an authority on the subject; possess skill and knowledge acquired by experience; have skill in the type of study; pass a specific test to identify judges; have a high rating, assigned by an authority. Emphasizes that at least two of these criteria should be met.

The criteria proposed by Pasquali(11) were adopted to choose the number of participating judges, which considers a number between six to twenty specialists. The selection of judges was carried out by sampling a net or snowball, which is used when the population is composed of people with characteristics that can be difficult to find.

In the process of clinical validation, of the 40 patients in the referred outpatient clinic, 31 agreed to participate, who followed the following inclusion criteria: presenting onco-hematological disease; be guided and in clinical condition to be interviewed; be at least 18 years old.

\section{Study protocol}

The study was carried out in five stages $\left.{ }^{(12)} .1\right)$ Integrative review of the scientific literature. The search occurred in the databases of Medical Literature Analysis and Retrieval System Online (MEDLINE/ Pubmed), Latin American and Caribbean Literature in Health Sciences (LILACS), Nursing database (BDENF) and Scopus, using the Health Sciences Descriptors and Medical Subject Headings (DeCS/ MeSH): "nursing" ("enfermagem"),"nursing diagnosis" ("diagnóstico de enfermagem"), "chemotherapy" ("quimioterapia") and "adverse effects" ("efeitos adversos"). The controlled descriptor used was "hematologic neoplasms" ("neoplasias hematológicas") associated through the Boolean operator AND to the aforementioned descriptors. Primary studies in full, published from 2012 to 2017, in English, Portuguese or Spanish were included. 2) Evaluation of empirical indicators through a focus group. This research technique, when used in the construction of indicators, aims to acquire consensus on the data found, which will later be analyzed by the researcher and transformed into instruments or devices ${ }^{(13)}$. This process took place from January to February 2018; 3) Construction of the data collection instrument; 4) Content validation by teaching and assisting judges; 5) Clinical validation with the target population.

The seven judges and four nurses received and delivered the signed Free and Informed Consent Form (ICF). The judges were 
sent via email the instrument to be evaluated and a script with the evaluation items, in addition to the instructions on how to complete it. This phase occurred from May to December 2018.

In the structuring of the instrument, the international Nursing Minimum Data Set (NMDS) was used, to obtain a concise, clear instrument with sufficient and necessary information for the initial assessment of the patient's health status ${ }^{(14)}$. The International Nursing Minimum Data set (NMDS) divides it into three categories, namely: patient demographic items, nursing care items and service items, which aim to obtain a concise, clear instrument with sufficient and necessary information to the initial assessment of the patient's health status ${ }^{(14)}$. However, psychobiological, psychosocial and psycho-spiritual needs were classified, based on the Theory of Basic Human Needs of Horta $(\mathrm{TBHN})^{(9)}$.

The relevance of the items was scored using a Likert scale, containing four levels of valuation: 1 - irrelevant; 2 - not very relevant; 3 - relevant and 4 - extremely relevant, in addition to space for suggestions. The first version of the instrument consisted of data from the institution, identification data, perceptions and expectations related to the disease and the set of SI distributed in the BHN classifications of Horta.

Regarding the collection with patients, they were invited to participate at the time of the nursing consultation. This process took place from May to December 2019. Two nursing assistants from the outpatient unit participated in the application of the nursing consultation instrument, as well as two researchers trained for this purpose, who are already working on extension projects in that clinic. During the interviews, notes of comments, opinions, and suggestions from nurses about the instrument were recorded.

\section{Analysis of results and statistics}

The data obtained in the focus group were coded, as recommended by $\operatorname{COREQ}^{(8)}$, into empirical indicators necessary to be included in the instrument. These empirical data were separated by the classification of Horta's nursing theory into psychobiological, psychosocial and psycho-spiritual needs ${ }^{(9)}$.

To determine the level of agreement between the judges in a quantitative way, the Content Validity Index (CVI) was calculated for each of the items and for the total set of items of the instrument. It should also be noted that all suggestions made by the judges were considered and analyzed in a descriptive manner. The data were analyzed in the Statistical Package for the Social Sciences (SPSS), version 20.0, and presented in tables.

The analyzed items were considered validated when the judges presented an agreement index $\geq 78 \%{ }^{(15)}$. Therefore, the item that did not reach this percentage was revised or deleted. At the same time, the reliability of the instrument was assessed by Cronbach's a test, considering the following values $>0.90$ - excellent, $>0.80$ - good, $>0.70$ - acceptable, $>0.60$ - questionable; $>0.50$ - poor and $<0.50$ unacceptable ${ }^{(16)}$

In the process of applying the instrument to the target population, for each item, the option to disagree or agree was considered. And in case of disagreement, a space to propose suggestions. This process allowed the verification of the pertinence and applicability of the proposed instrument.

\section{RESULTS}

\section{$1^{\text {st }}$ stage: Identification of empirical indicators}

The search resulted in a sample of 27 articles, in which 83 IE related to human needs were identified, being distributed according to each level of need described by Horta, equivalent to 60 in psychobiological needs, 22 in psychosocial needs and one in psycho-spiritual need.

\section{$2^{\text {nd }}$ stage: Evaluation of empirical indicators by the focus group}

The nurses who made up the focus group were aged between 39 and 51 years, among whom, one was a master and three specialists, with experience in the area of oncology nursing between four and 20 years. The changes and suggestions were recorded on a form and, after obtaining the consensus opinion, a summary of the discussions was presented.

According to the suggestions, four IE were repositioned, inserted in the psychobiological needs (psychological stress, insomnia, hyperglycemia and fatigue). The items insomnia and fatigue were reallocated to the need for sleep and rest. The item psychological stress was reallocated to the need for emotional security and the item hyperglycemia to the need for hormonal regulation. There was an addition of $20 \mathrm{IE}$ related to 10 classifications of psychobiological needs and nine indicators referring to five classifications of psychosocial needs. There was also a change in the writing of some IE and addition of items referring to the institution's data, identification data and perceptions/expectations related to the disease. These recommendations followed the principles outlined in COREQ.

\section{$3^{\text {rd }}$ stage: Construction of the data collection instrument}

The built instrument had 146 items and was organized by topics, namely: data from the institution; identification data, perception and expectations related to the disease; assessment of psychobiological needs; assessment of psychosocial and spiritual needs, all with their respective items (indicators).

\section{$4^{\text {th }}$ stage: Validation of the instrument with judges}

All the judges who evaluated the instrument were female, predominantly in the age group 41 to 50 years old (42.8\%), 21 to 30 years of professional training $(57.1 \%)$ and with degrees from doctors and masters (42, 8\% each). Regarding the length of experience in the oncology field, judges with experience between 17 and 21 years old (42.8\%) prevailed, with the majority (42.8\%) exercising teaching and assistance activities. The consent of the responses remained between 86 to $100 \%$. Of the 146 items evaluated, 143 obtained agreement above $78 \%$ of the judges. The instrument's CVI as a whole reached $95 \%$ CVI, thus ensuring content validity and the representativeness of the instrument for collecting nursing data in the target population. In addition, Cronbach's alpha (a) test was 0.93 , which demonstrated excellent instrument reliability. 
Regarding psychosocial needs, the items "number of rooms in the residence, number of family members and privacy at home", belonging to the need for space, obtained CVI equal to $71 \%$, therefore being excluded from the instrument.

Despite the satisfactory results obtained, it was decided to consider the suggestions for inclusion, exclusion and repositioning of items proposed by the judges, in order to improve the instrument.

Table 1 - Distribution of instrument items that obtained 100\% Content Validity Index, Fortaleza, Ceará, Brazil, 2017

\begin{tabular}{|c|c|c|}
\hline & & CVI \\
\hline \multicolumn{3}{|c|}{ ASSESSMENT OF PSYCHOBIOLOGICAL NEEDS } \\
\hline Oxygenation & $\begin{array}{l}\text { Respiratory rate, Dyspnea } \\
\text { Cough, Sputum } \\
\text { Secretion characteristic }\end{array}$ & 1.0 \\
\hline Nutrition & $\begin{array}{l}\text { Weight/Height/BMI, Weight Loss } \\
\text { Malnutrition, Obesity } \\
\text { Anorexia, Odynophagia } \\
\text { Dysphagia, Xerostomia, } \\
\text { Nausea, Type of diet/number of } \\
\text { meals/day, Appetite }\end{array}$ & 1.0 \\
\hline Elimination & $\begin{array}{l}\text { Urinary and Intestinal (frequency } \\
\text { / characteristic) } \\
\text { Dysuria, Hematuria } \\
\text { Anuria, Oliguria } \\
\text { Polyuria, Urinary incontinence } \\
\text { Diarrhea, Constipation } \\
\text { Vomit, Melena }\end{array}$ & 1.0 \\
\hline Sleep and rest & $\begin{array}{l}\text { Sleep Habit/Period/Duration } \\
\text { Insomnia, Drowsiness } \\
\text { Fatigue: frequency/time of } \\
\text { greatest fatigue }\end{array}$ & 1.0 \\
\hline Physical activity & Exercise, Physical limitation & 1.0 \\
\hline Physical integrity & $\begin{array}{l}\text { Whole skin, Bruises } \\
\text { Petechiae, Mucositis } \\
\text { Skin infections } \\
\text { Pallor, Hives } \\
\text { Adenomegalies, Other skin } \\
\text { lesions }\end{array}$ & 1.0 \\
\hline $\begin{array}{l}\text { Cell growth and } \\
\text { functional development }\end{array}$ & $\begin{array}{l}\text { Neutropenia, Thrombocytopenia } \\
\text { Anemia, Alopecia } \\
\text { Neutrophil/platelet/hemoglobin } \\
\text { values }\end{array}$ & 1.0 \\
\hline Thermal regulation & Temperature, Cold/Chills & 1.0 \\
\hline Neurological regulation & $\begin{array}{l}\text { Consciousness } \\
\text { Confusion, Anxiety } \\
\text { Depression, Drowsiness } \\
\text { Tingling, Numbness } \\
\text { Muscle weakness }\end{array}$ & 1.0 \\
\hline Hormonal regulation & $\begin{array}{l}\text { Glycemic levels, Excessive thirst } \\
\text { Frequent urination, severe } \\
\text { hunger } \\
\text { Easy tiredness }\end{array}$ & 1.0 \\
\hline Sensoperception & Pain, Dysgeusia & 1.0 \\
\hline Therapy and prevention & $\begin{array}{l}\text { Emotional support, Information } \\
\text { support } \\
\text { Family support, Social support } \\
\text { Economic support, Form of } \\
\text { treatment adherence }\end{array}$ & 1.0 \\
\hline
\end{tabular}

Table 1 (concluded)

CVI

EVALUATION OF PSYCHOSOCIAL AND PSYCHOSPIRITUAL NEEDS

Communication

Speech disorders

Difficulty understanding what

professionals say

Gregaria

Feel support from the family/

Social relations

Receives financial support from

family for treatment

Recreation and leisure

Participates in recreation and leisure activities

Emotional security

Anguish/Stress/Hopelessness, Concerns/Uncertainty/Fear of the spread and/or recurrence of cancer/Suffering/Despair

Love, acceptance

Feels rejected and stigmatized by people

Problems in the relationship with your partner after diagnosis and treatment

Self-esteem, selfconfidence and self-

Decreased self-esteem, Shame Altered body image respect Religiosity/spirituality

Has religion, belief or faith

Note: CVI - Content Validity Index; BMI - Body Mass Index.

Chart 1 - Suggestions for changes to items in the data collection instrument, according to the analysis of the judges, Fortaleza, Ceará, Brazil, 2017

\begin{tabular}{|l|}
\hline INSTRUMENT ITEM CHANGES SUGGESTIONS \\
\hline Data identification \\
\hline $\begin{array}{l}\text { Replace "age" with "date of birth", include "sex", "race" and "number } \\
\text { of cycles of the chemotherapy protocol", include the "initial, relapse, } \\
\text { palliative" treatment phase and "previous treatments"; include } \\
\text { "hematopoietic stem cell transplantation: type, date and complications" }\end{array}$ \\
\hline Perceptions and expectations related to the disease \\
\hline Include "drug intolerance" \\
\hline Assessment of psychobiological needs \\
\hline $\begin{array}{l}\text { Include "type of liquid ingested" in the need for hydration; include } \\
\text { "fatigue level" in the need for sleep and rest; exclude the items } \\
\text { "increased risk of complications and increased risk of mortality" in } \\
\text { the need for physical security and the environment; include "change } \\
\text { in temperature in the last week" in the need for thermal regulation; } \\
\text { include "dizziness and vertigo" in the need for hormonal regulation }\end{array}$ \\
\hline Assessment of psychosocial needs \\
\hline $\begin{array}{l}\text { Replace"exercise paid activities" with"have a fixed income source" in the } \\
\text { need to } \\
\text { self-realization; include "face the disease positively" in the need for security } \\
\text { emotional }\end{array}$ \\
\hline Assessment of psycho-spiritual needs \\
\hline \begin{tabular}{l} 
Including "are you a practitioner?" in need of religiosity \\
\hline
\end{tabular} \\
\hline
\end{tabular}

The changes suggested by the expert judges are organized and presented in Chart 1.13 suggestions for changes were accepted, these suggestions referring to items of the instrument that presented CVI greater than $0.78 \%$. 


\section{$5^{\text {th }}$ stage: Validation of the instrument with the target population}

After the stage of validation by judges, validation was carried out with the target population. Through the application of consultation instruments, it was possible to characterize 31 onco-hematological patients treated at a chemotherapy outpatient clinic. Their average age was 50.94 years, along with this, $54.1 \%$ were female, $60.7 \%$ were married and $36 \%$ had finished high school. The most frequent medical diagnoses were Non-Hodgkin's Lymphoma (48.4\%), in its various subtypes; Hodgkin's lymphoma (19.4\%); Multiple Myeloma (16.1\%).

The item Knowledge about the disease and treatment was removed, belonging to the segment "Perceptions and expectations related to the disease".The change is justified, as this information was included in other items of the instrument.

In the Psychobiological needs segment, the items"weight loss" and "obesity" were eliminated, since the items weight, height and BMI were already included in the Nutrition domain, making the data repetitive. The item "dysgeusia", which used to be in the Sensoperception domain, was reallocated to the Nutrition domain, since, at the time of the nursing consultations, it was found that it was more appropriate to ask the patient along with similar questions, such as xerostomia and dysphagia.

In the Regulation domain: cell growth and functional development, the terms"neutropenia", "anemia" and "thrombocytopenia" were replaced by items with space to record the hemogram values (neutrophils, hemoglobin, and platelets), as the value of these parameters in oncohematology is more relevant than just the classification ${ }^{(17)}$.

In the field of Therapeutics and prevention, the following items were relocated:"need for emotional support", "need for information support", "need for family support". These changes are justified, as they are obtained in other items of the instrument referring to psychosocial needs, such as Gregaria, Emotional security and Education for health and learning, facilitating the approach by the interviewer at the time of the interview.

In the emotional security domain, it was observed that patients tended to limit their report of coping with the disease to religious issues. In view of this, the Religiosity/Spirituality domain was reallocated, preceding the Emotional Security domain, to allow the interviewer to address other aspects of coping with the disease. The question "How did Mr./Mrs. Do you face the disease? "to allow an opening by the researcher to address the subject. The items "concern" and "suffering" were also removed, as it was assessed that they did not characterize a way of coping with the disease, as well as the item "avoidance", for observing patients who did not like to talk about the subject. In the domain Education for health and learning, the item Coping, previously discussed, was removed, becoming repetitive at the time of the nursing consultation.
It was also observed the need for more space for effective registration of the evaluated aspects, justifying changes in the instrument's layout. Thus, considering the pertinence of the items added referring to the judges' suggestions and during the clinical validation process, the final version of the instrument was elaborated, which now has 178 items and greater availability of space for recording information (Figure 1).

\section{DISCUSSION}

The built instrument, called "Data collection instrument for oncohematological patients", consists of identification data, perceptions and expectations related to the disease, as well as the assessment of psychobiological, psychosocial and psycho-spiritual needs.

Patient identification data are relevant in the instrument for the first stage of the nursing process, as they belong to the set of essential nursing elements that meet the information needs of various users in the health system ${ }^{(18)}$.

A suggestion by the judges turned to the inclusion and association of the item "drug intolerance" with the item "drug allergy". 
These data were evaluated as relevant, since it is essential for nurses to know and register allergies and drug intolerances. The knowledge and recording of this information supports an adequate analysis of prescriptions and nursing care, being listed as good practices in the administration of chemotherapy ${ }^{(19)}$.

The changes recommended by the judges regarding psychobiological needs were focused on the topic of hydration and sleep. In the topic of rest, the importance of measuring the intensity of fatigue was added. The high prevalence of fatigue in this population is highlighted, being disabling and detrimental to the quality of life, in addition to being underestimated and underreported. In addition to being reported as one of the most important and stressful symptoms related to cancer and its treatment ${ }^{(20)}$.

Still regarding psychobiological needs, the topic "thermal regulation" was marked by the increase in the presence of fever in the last week. Fever is a warning sign and, when associated with neutropenia, is considered an oncological emergency. The administration of antibiotic therapy in a timely manner is related to better outcomes. Nursing participates in the management of neutropenic fever, acting in the identification of the event and intervening by providing information to the patient, an important part of the management ${ }^{(17)}$.

The indicators "dizziness and vertigo" were also added to the instrument because they are symptoms that suggest changes in blood glucose levels ${ }^{(21)}$. Vertigo is one of the forms of dizziness, being a hallucination of movement, rotational or translational. Vertigo patients report feeling of movement, even in a static position $^{(22)}$. In acute lymphocytic leukemias, episodes of hyperglycemia may occur during the therapeutic induction protocol, due to the concomitant administration of corticosteroids. Early detection and treatment of hyperglycemia are fundamental steps in the prevention of acute complications, such as non-ketoacidotic hyperglycemic syndrome ${ }^{(23)}$.

In the psychosocial and psycho-spiritual needs, the question of exercising paid activity and / or fixed income were considered relevant by the judges, as well as how the individual coped with the disease.

Coping is nothing more than an adaptive change to the environment, which can be positive or negative, depending on the defense mechanisms employed. Such records add relevance to the instrument, since a person's health is influenced by socioeconomic determinants. Therefore, coping with patients may be focused on emotion, through the search for social support or information, as well as the search for religious practices, assimilating thoughts of hope that serve to assist in coping with cancer $^{(24)}$. Knowing this aspect goes against what is recommended for the nurse's work on what to investigate in an outpatient context ${ }^{(25)}$. In the validation process with the target audience, avoidance was seen as a way of coping, and for this reason, it was included in the instrument.

The item practice of religion was added to the instrument to have belief or faith, considering that the religious and spiritual aspects differ and must be understood and valued ${ }^{(26)}$. The use of religion, spirituality or faith as a coping strategy in the face of unfavorable contexts is called spiritual/religious coping. Individuals who have positive coping strategies also have high levels of hope. Thus, in the relationship with the patient and family, the nurse must identify the religious and spiritual needs of the binomial, providing care focused on spirituality, using their coping strategies in maintaining hope ${ }^{(27)}$. This element can contribute to treatment adherence $^{(28)}$. It is noteworthy that, during the validation with patients, the religious issue emerged in almost all consultations as a means of coping with the disease/treatment.

The validation with the target audience confirmed the relevance of the items contained in the instrument validated by the judges, and most of the changes made in this process of clinical validation referred to structural changes, reallocation of items in other domains and items that were found, repeated, in a way.

Nursing has an important role of facilitator and mediator for the patient to contemplate his biological, psychological, social and spiritual needs. Therefore, it is believed that the use of the built instrument may contribute to the practice of oncologist nurses who work in an outpatient unit, as it translates items relevant to nursing research.

\section{Study limitations}

During the development of the research, limitations were found, such as the difficulty of elaborating a brief instrument so as not to make the application in care practice unfeasible, but that, nonetheless, included minimum essential items to guarantee quality care. Another limitation was the difficulty in defining judges, in view of the difficulty of being conceptualized in its entirety. The criterion used in the study was that of Jasper, who considers items of clinical experience, but there is no guarantee that all prerequisites are, in fact, a guarantee of clinical expertise. Furthermore, failure to perform field validation with nurses is also a limitation of the present study.

\section{Contributions to the field of nursing, health or public policy}

It is believed that the elaboration and validation of the nursing data collection instrument, based on $\mathrm{BHN}$ and directed to onco-hematological patients, constitutes the first step to assess the real needs of this clientele, enabling the planning and implementation of interventions appropriate and individualized within the outpatient context. Thus, it will be possible to contribute to the nursing process, aiming to share and expand care for the target audience.

\section{CONCLUSIONS}

The constructed instrument was submitted to content validation by seven expert judges, in addition to clinical validation with 31 patients. The results showed that the scores attributed by the judges validated most of the items contained in the instrument. The instrument's CVI as a whole reached $95 \%$. Therefore, ensuring content validity and the representativeness of the instrument for collecting nursing data in the target population. In addition, Cronbach's alpha test was 0.93 , which demonstrated excellent reliability of the instrument. The clinical validation allowed the improvement of the instrument and obtained a final version with 178 items. Thus, the instrument is a valid technology to assist nurses in data collection and will serve as a tool for oncohematological nursing care, teaching and research. 
Finally, it is hoped that the elaborated and validated data collection instrument will be inserted as a nursing care management tool, since this step, which is essential to the nursing process, when well structured, will provide support for the other steps. In addition to providing nursing assistants with the development of critical thinking and clinical reasoning in the preparation of nursing diagnoses and in the establishment of appropriate and specific nursing interventions.

\section{REFERENCES}

1. Andrade A, Sawada NO, Barichello E. The quality of life of patients with hematological neoplasms undergoing chemotherapy. Rev Esc Enferm [Internet]. 2013 [cited 2017 Apr 17];47(2):350-6. Available from: http://www.scielo.br/pdf/reeusp/v47n2/en_12.pdf

2. Ferreira JN, Correia LRBR, Oliveira RM, Watanabe NA, Possari JF, Lima AFC. Managing febrile neutropenia in adult cancer patients: an integrative review of the literature. Rev Bras Enferm[Internet]. 2017 [cited 2017 Feb 15];70(6):1301-8. Available from: http://www.scielo.br/ $\mathrm{pdf} / \mathrm{reben} / \mathrm{v} 70 \mathrm{n6} / 0034-7167-$ reben-70-06-1301.pdf

3. Ministério da Saúde (BR). Instituto Nacional de Câncer José Alencar Gomes da Silva. ABC do câncer: abordagens básicas para o controle do câncer [Internet]. 3. ed. Rio de Janeiro: Inca; 2017[cited 2016 Jan 07]. 108 p.. Available from: http://www1.inca.gov.br/inca/Arquivos/ comunicacao/livro_abc_3ed_8a_prova_final.pdf

4. Silva FCF, Cunha CS, Feitosa TSRGT, Silva ADM, Sousa IDB. Assistência de enfermagem a pacientes com câncer em cuidados paliativos: revisão integrativa. Rev Enferm Atual Derme [Internet]. 2020 [cited 2020 Dec 01];91(29):149-57. Available from: https:// revistaenfermagematual.com/index.php/revista/article/view/626

5. Kousoulou M, Suhonen R, Charalambous A. Associations of individualized nursing care and quality oncology nursing care in patients diagnosed with cancer. Europ J Oncol Nurs. 2019;41(1):33-40. https://doi.org/10.1016/j.ejon.2019.05.011

6. Oliveira TR, Martins BCT, Rocha ME, Gomes NS, Aires VGS. Sistematização da Assistência de Enfermagem: análise da produção científica em oncologia: revisão integrativa. Braz J Develop. 2020;6(2):9541-55. https://doi.org/10.34117/bjdv6n2-314

7. Rodrigues $A B$, Cunha GH, Aquino $C B Q$, Rocha SR, Firmeza MA, Grangeiro ASM. Head and Neck cancer: validation of a data collection instrument. Rev Bras Enferm. 2018;71(4):1899-60. https://doi.org/10.1590/0034-7167-2017-0227

8. Tong A, Sains Bury P, Craig J. Consolidated Criteria for Reporting Qualitative Research (COREQ): a 32-Item Checklist for Interviews and Focus Groups. Int J Qual Health Care [Internet]. 2007 [cited 2019 Jun 30];19(6):349-57. Available from: http://intghc.oxfordjournals.org/ content/19/6/349.full-text.pdf

9. Horta WA. Processo de enfermagem. São Paulo: EPU; 1979.

10. Jasper MA. Expert: a discussion of the implications of the concept as used in nursing. J Adv Nurs. [Internet]. 1994 [cited 2017 Oct 18];20(4):76976. Available from: https://onlinelibrary.wiley.com/doi/abs/10.1046/j.1365-2648.1994.20040769.x

11. Pasquali L. Psicometria: teoria dos testes na psicologia e na educação. Petrópolis: Vozes; 2016.

12. Guimarães $\mathrm{PV}$, Haddad $\mathrm{PCL}$, Martins RAPJ. Validação de instrumento para avaliação de pacientes graves em ventilação mecânica, segundo o ABCDE. Rev Eletron Enferm. 2015;17(1):43-50. https://doi.org/10.5216/ree.v17i1.23178

13. Braccialli LAD, Francisco AM, Moraes MAA, Carvalho MHR, Marvulo MML, Almeida Filho OM. Construção de indicadores de avaliação de processo de aprendizagem para um curso de enfermagem. Rev Eletron Enferm [Internet]. 2013 [cited 2017 Oct 04];17(1):51-9. Available from: https://www.fen.ufg.br/fen_revista/v17/n1/pdf/v17n1a06.pdf

14. Werley HH. The nursing minimum data set: abstraction tool standardized, comparable, essential data. Am J Pub Nurs [Internet]. 1991 [cited 2017 Mar 17];8(4):421-6. Available from: https://www.ncbi.nlm.nih.gov/pmc/articles/PMC1405031/

15. Polit DF, Beck CT. Fundamentos da pesquisa em enfermagem: avaliação de evidências para a prática de enfermagem. 7. ed. Porto Alegre: Artmed; 2011.

16. George D, Mallery P. SPSS for Windows step by step: a simple guide and reference. 11.0 update. 4. ed. Boston: Ally \& Bacon; 2010.

17. Koenig C, Morgan J, Ammann RA, Sung L, Phillips B. Protocol for a systematic review of time to antibiotics (TTA) in patients with fever during chemotherapy for cancer (FN) and interventions aiming to reduce TTA. Sistem Rev[Internet]. 2019 [cited 2020 Mar 19];8(82). Available from: https://www.ncbi.nlm.nih.gov/pmc/articles/PMC6446276/

18. Marques DKA, Souza GLL, Silva AB, Silva AF, Nóbrega MML. Conjunto Internacional de Dados Mínimos de Enfermagem: estudo comparativo com instrumentos de uma clínica pediátrica. Rev Bras Enferm[Internet]. 2014 [cited 2018 Feb 09];67(4):588-93. Available from: http://www. scielo.br/pdf/reben/v67n4/0034-7167-reben-67-04-0588.pdf

19. Oliveira PP, Santos VEP, Bezerril MS, Andrade FB, Paiva RM, Silveira EAA. Pacient safety in the administration of antineoplastic chemotherapy and of immunotherapics for oncological treatment: scoping review. Texto Contexto Enferm. 2019;28(1):e20180312. https://doi. org/10.1590/1980-265x-tce-2018-0312

20. Batista DRR, Mattos M, Silva SF. Convivendo com o câncer: do diagnóstico ao tratamento. Rev Enferm UFSM [Internet]. 2015 [cited 2018 Jul 01];5(3):499-510. Available from: https://periodicos.ufsm.br/reufsm/article/view/15709/pdf

21. Pereira CFN, Cruz ICF. A construção de um protocolo glicêmico efetivo no controle da hipoglicemia em UTI: revisão sistematizada da literatura. J Spec Nurs Care [Internet]. 2018 [cited 2020 Mar 20];10(1). Available from: http://www.jsncare.uff.br/index.php/jsncare/article/view/2986/758 
22. Troncoso AT, Nunes CP. Discussão de vertigem, labirintite e diagnósticos diferenciais. Rev Med Fam Saúde Mental [Internet]. 2019 [cited 2020 Mar 20];1(2). Available from: http://www.revista.unifeso.edu.br/index.php/medicinafamiliasaudemental/article/view/1601/631

23. Palma RP, Folatre BI, Kyonen LM, Cea SG, Yilorm BM, Martínez DP. Hiperglicemia en niños con leucemia linfoblástica aguda en tratamiento con L-asparaginasa. Rev Chil Pediatr. 2013;84(4):387-95. https://doi.org/10.4067/S0370-41062013000400004

24. Oliveira PF, Queluz FNFR. A Espiritualidade no Enfrentamento do Câncer. Rev Psicol IMED [Internet]. 2016 [cited 2018 Feb 11];8(2):142-55. Available from: https://seer.imed.edu.br/index.php/revistapsico/article/download/1314/1036

25. Chavoni RC, Silva PB, Ramos GHA. Diagnóstico nutricional de pacientes do serviço de cabeça e pescoço e sua relação com a disfagia em um hospital oncológico do Paraná. Rev Bras Cir Cabeça Pescoço [Internet]. 2014 [cited 2018 Feb 17]:43(1):35-41. Available from: http://www. sbccp.org.br/wp-content/uploads/2014/04/Revista-SBCCP-43-1-Artigo-07.pdf

26. Sousa FFPR, Freitas SMFM, Farias AGS, Cunha MCSO, Araújo MFM, Veras VS. Religious/Spiritual coping by people with cancer undergoing chemotherapy: integrative literature review. Rev Eletron Saúde Mental Álcool Drogas[Internet]. 2017 [cited 2018 Mar 14];13(1):45-51. Available from: http://pepsic.bvsalud.org/pdf/smad/v13n1/07.pdf

27. Costa DT, Silva DMR, Cavalcanti IDL, Gomes ET, Vasconcelos JLA, Carvalho MVG. Religious/spiritual coping and level of hope in patients with cancer in chemotherapy. Rev Bras Enferm [Internet]. 2019 [cited 2020 Mar 19];72(3):640-45. Available from: http://www.scielo.br/pdf/reben/ v72n3/0034-7167-reben-72-03-0640.pdf

28. Pinto AC, Marchesini SM, Zugno PI, Zimmermann KG, Dagostin VS, Sorotto MT. A importância da espiritualidade em pacientes com câncer. Rev Saúde Com [Internet]. 2015 [cited 2018 Mar 01];11(2):114-22. Available from: http://www.uesb.br/revista/rsc/v11/v11n2a02.pdf 